\title{
EFFECTS OF Citrus hystryx AS FAT PROTECTOR ON UNSATURATED FATTY ACIDS, CHOLESTEROL AND CHEMICAL COMPOSITION OF LAMB MEAT
}

\author{
N. C. Tiven, I. P. Siwa and L. Joris \\ Agriculture Faculty, Pattimura University, \\ Jln. Ir. M. Putuhena Kampus Poka, Ambon 97233 - Indonesia \\ Corresponding E-mail: nafly_tiven@yahoo.co.id \\ Received February 01, 2016; Accepted Febraury 27, 2016
}

\begin{abstract}
ABSTRAK
Penelitian ini dilakukan untuk mengetahui efek jeruk purut (Citrus hystrix) sebagai protektor terhadap asam lemak tidak jenuh, kolesterol dan komposisi kimia daging. Rancangan penelitian yang digunakan adalah rancangan acak lengkap dengan 3 perlakuan dan 5 kali ulangan. Sebanyak 15 ekor domba lokal jantan berumur 9-12 bulan dengan bobot badan 14-17 kg, dibagi menjadi 3 kelompok perlakuan ransum (P0 : domba yang hanya diberi ransum basal; P1 : domba yang diberi ransum basal dan 3\% minyak goreng; P2 : domba yang diberi ransum basal dan 3\% minyak yang diproteksi dengan 3\% bubuk jeruk purut. Data dianalisis statistik menggunakan analisis sidik ragam, perbedaan antar perlakuan diuji lanjut dengan Duncan's New Multiple Range Test. Hasil penelitian menunjukkan bahwa daging dari domba yang mengkonsumsi ransum P2 mempunyai total kadar asam lemak dan kandungan asam lemak poli tak jenuh yang lebih tinggi $(\mathrm{P}<0,01)$ dengan kadar kolesterol yang lebih rendah $(\mathrm{P}<0,01)$ dibanding $\mathrm{P} 0$, serta mempunyai kadar protein dan kadar lemak yang lebih tinggi $(\mathrm{P}<0,01)$, dengan kadar air yang lebih rendah $(\mathrm{P}<0,01)$ dibanding $\mathrm{P} 0$. Disimpulkan bahwa penggunaan jeruk purut sebagai protektor lemak dapat meningkatkan kadar asam lemak poli tak jenuh, kadar protein dan kadar lemak, tetapi menurunkan kadar kolesterol.

Kata kunci : jeruk purut, protektor lemak, asam lemak tidak jenuh, cholesterol, komposisi kimia, daging
\end{abstract}

\begin{abstract}
This study was conducted to determine the effect of Citrus hystrix as fat protector on unsaturated fatty acids, cholesterol and chemical composition of lamb meat. The research design applied was completely randomized design with 3 treatments and 5 replications. Fifteen local male lambs aged 9-12 months weighing 14-17 kg, were divided into 3 groups of different diet treatments (P0 : sheeps were only given a basal diet; P1 : sheeps are given basal diet and 3\% cooking oil; P2 : sheeps are given basal diet, $3 \%$ cooking oil and protected by 3\% Citrus hystrix powder). The data were analyzed by analysis of variance, the differences among treatments were tested by Duncan's New Multiple Range Test. The results showed meat from sheeps that consume $\mathrm{P} 2$ diet has a total fatty acid and polyunsaturated fatty acids content were higher $(\mathrm{P}<0.01)$, with lower cholesterol content $(\mathrm{P}<0.01)$ than of $\mathrm{P} 0$, and has a protein and fat content were higher $(\mathrm{P}<0.01)$, but a lower water content $(\mathrm{P}<0.01)$ than that of $\mathrm{PO}$. It can be concluded that the use of Citrus hystrix powder as fat protector can increase content of polyunsaturated fatty acids, protein and fat, but decrease cholesterol content.

Keywords: citrus hystrix, fat protector, unsaturated fatty acids, cholesterol, meat, chemical composition
\end{abstract}




\section{INTRODUCTION}

Unsaturated fatty acids in the diet, among others linoleic (cis-9, cis-12-18:2) and linolenic (cis-9, cis-12, cis-15-18:3) will be hydrogenated by rumen microbes, so that only $10 \%$ have joined the lipid tissue (Wood et al., 2008), while 90\% hydrogenated into saturated fatty acids (Drackley, 2007). One of the efforts of nutritionists to reduce the hydrogenation is to protect the unsaturated fatty acids. The protection unsaturated fatty acids sources of the diet using a 3\% formaldehyde $\left(\mathrm{CH}_{2} \mathrm{O}\right)$, can protect unsaturated fatty acids of the hydrogenation process (Tiven et al., 2011a), is not negatively effect on fermentation parameters and rumen microbial activity (Tiven et al., 2011b), increasing the unsaturated fatty acids in rumen fluid, blood and meat (Tiven et al, 2013), lowers blood and meat cholesterol (Tiven, 2011) and also improve the physical and chemical quality of lamb meat (Tiven et al., 2015). The success of this research has not been widely accepted by the public, because the hazard of formaldehyde. This drives the need a source of natural aldehydes that can be used to protect a source of unsaturated fatty acids in the diet.

The Citrus hystrix is one of the plants that contain natural aldehydes, namely citronellal, with a content of $81.49 \%$ on the leaves. Potential natural aldehydes were tested in vitro, with protecting cooking oil as a source of unsaturated fatty acids in the diet. The results show that $3 \%$ Citrus hystrix leaves powder and 3\% cooking oil gives a better effect $(\mathrm{P}<0.01)$, which can increase unsaturated fatty acids and not negative effect on the fermentation parameters and microbial activity. These results are used in the in vivo study to determine the effect of Citrus hystrix as fat protector on unsaturated fatty acids, cholesterol and meat chemical composition.

\section{MATERIALS AND METHODS}

\section{Animals}

Fifteen of local male lambs aged 9-12 months with a body weight of about $14-17 \mathrm{~kg}$ were maintained in individual cages shaped stage equipped with places to eat and drink. Sheeps were randomly divided into 3 groups according to the treatment of feed; each group consisted of 5 animals.

\section{Feed}

Basal diet was consisted of forage and concentrate with a ratio of $60: 40$. Forage used was elephant grass, while the concentrates were consisted of $30 \%$ rice bran and $10 \%$ soybean meal. Nutrient contents of basal ration were $62.98 \%$ of total digestible nutrients, $45.5 \%$ of dry matter, $14.48 \%$ of crude protein, $4.70 \%$ of crude fat and $21.93 \%$ of crude fiber. The first group received only the basal diet ( $\mathrm{P} 0)$, the 2 nd group received the basal diet, and 3\% cooking oil $(\mathrm{P} 1)$, while the 3rd group received the basal diet, 3\% cooking oil protected with 3\% Citrus hystrix powder (P2).

\section{Chemical and Physical Meat Properties}

After feed treatment for 3 months, sheep were slaughtered. Halal slaughter method was applied, starting with the neck cut to the jugular vein severed, esophagus, and trachea (near the lower jaw bone). The Longissimus dorsi (LD) muscle on the back of the carcass were taken for analysis of fatty acid, cholesterol and chemical meat composition (AOAC, 2012).

\section{Statistical Analysis}

The data were analyzed by analysis of variance with completely randomized design. The differences between treatments were tested further by Duncan's new multiple range test. Data processing is done with the SPSS program 17.0 for Windows Evaluation Version (Oramahi, 2008).

\section{RESULTS AND DISCUSSION}

\section{The Effect of Citrus hystrix As Fat Protector On Fatty Acid and Cholesterol of Lamb Meat}

Statistical analysis result showed that the treatment was significant $(\mathrm{P}<0.01)$ on saturated fatty acid (SAFA), monounsaturated fatty acid (MUFA), polyunsaturated fatty acid (PUFA) and total fatty acids of lamb meat (Table 1). The value of total fatty acids in the lamb meat that were given $\mathrm{P} 2$ diet, higher than of $\mathrm{P} 1$ and $\mathrm{P} 0$. The high total fatty acids in $\mathrm{P} 2$ is caused by the high SAFA, among others myristic and palmitic. This shows that the use Citrus hystrix powder as protector fat in the diet (P2) has not been able to decrease the saturated fatty acids in meat lamb. However, the results also showed that the use Citrus hystrix powder as fat protector in the diet can increase of polyunsaturated fatty acids PUFA, caused by the high linoleic and linolenic. This shows that protection cause linoleic and linolenic escapes from the rumen microbial hydrogenation and can join the lipid tissue. 
Table 1. The Average Fatty Acid (\%) and Cholesterol Content (mg/100g) of Lamb Meat with Fat Protection

\begin{tabular}{lccc}
\hline \multirow{2}{*}{ Fatty Acid } & \multicolumn{3}{c}{ Treatment } \\
\cline { 2 - 4 } & \multicolumn{1}{c}{ P0 } & \multicolumn{1}{c}{ P1 } & \multicolumn{1}{c}{ P2 } \\
\hline Myristic (C14:0) & $1.45 \pm 0.03^{\mathrm{c}}$ & $2.01 \pm 0.00^{\mathrm{b}}$ & $2.45 \pm 0.01^{\mathrm{a}}$ \\
Palmitic (C16:0) & $20.72 \pm 0.11^{\mathrm{c}}$ & $21.92 \pm 0.14^{\mathrm{b}}$ & $27.32 \pm 0.09^{\mathrm{a}}$ \\
Stearic (C18:0) & $1.39 \pm 0.11$ & $1.52 \pm 0.09$ & $1.43 \pm 0.06$ \\
Oleic (C18:1) & $36.18 \pm 0.21^{\mathrm{a}}$ & $34.30 \pm 0.12^{\mathrm{b}}$ & $28.55 \pm 0.19^{\mathrm{c}}$ \\
Linoleic (C18:2) & $30.24 \pm 0.38^{\mathrm{a}}$ & $28.67 \pm 0.20^{\mathrm{b}}$ & $30.68 \pm 0.27^{\mathrm{a}}$ \\
Linolenic (C18:3) & $1.42 \pm 0.45^{\mathrm{c}}$ & $3.22 \pm 0.30^{\mathrm{a}}$ & $2.21 \pm 0.31^{\mathrm{b}}$ \\
SAFA & $23.56 \pm 0.24^{\mathrm{c}}$ & $25.44 \pm 0.05^{\mathrm{b}}$ & $31.15 \pm 0.16^{\mathrm{a}}$ \\
MUFA & $36.18 \pm 0.21^{\mathrm{a}}$ & $34.30 \pm 0.12^{\mathrm{b}}$ & $28.55 \pm 0.19^{\mathrm{c}}$ \\
PUFA & $31.66 \pm 0.07^{\mathrm{c}}$ & $31.89 \pm 0.10^{\mathrm{b}}$ & $32.89 \pm 0.05^{\mathrm{a}}$ \\
Total & $91.39 \pm 0.11^{\mathrm{c}}$ & $91.63 \pm 0.06^{\mathrm{b}}$ & $92.62 \pm 0.01^{\mathrm{a}}$ \\
Cholesterol & $23.71 \pm 1.23^{\mathrm{a}}$ & $18.51 \pm 0.36^{\mathrm{c}}$ & $21.48 \pm 0.58^{\mathrm{b}}$ \\
\hline
\end{tabular}

Different superscripts in the same row indicate significantly different $(\mathrm{P}<0.01)$

\section{Cholesterol}

Statistical analysis showed that the treatment was significant $(\mathrm{P}<0.01)$ on meat lamb cholesterol. This shows that the use of Citrus hystrix powder as fat protector in the diet (P2) can lower cholesterol in lamb meat, which caused by increase of PUFA, but still higher than P1. This contrasts with Tiven (2011), that blood cholesterol levels tend to decrease when the sheeps were given the diet with addition of $\mathrm{CPO}$ protected with formaldehyde, which caused by decrease SAFA $(\mathrm{P}<0.01)$ of $12.17 \mathrm{~g} / 100 \mathrm{~g}$ and increased MUFA and PUFA $(\mathrm{P}<0.01)$ respectively amounted to $5.07 \mathrm{~g} / 100 \mathrm{~g}$ and $1.01 \mathrm{~g} / 100 \mathrm{~g}$. Level of cholesterol in this study, between 18.51-23.71 $\mathrm{mg} / 100 \mathrm{~g}$ (average $21.23 \mathrm{mg} / 100 \mathrm{~g}$ ), lower than Tiven (2011), which protects the CPO with formaldehyde, with cholesterol levels of meat lamb between 45.11-46.95 mg/100 g (average $46.17 \mathrm{mg} / 100 \mathrm{~g})$.

\section{Chemical Composition of Lamb Meat Water Content}

Statistical analysis showed that the treatment was significant $(\mathrm{P}<0.01)$ on water content of lamb meat (Table 2). The value of water content in the lamb meat that were given P2 diet, lower than P1 and $\mathrm{P} 0$. This decrease in water content caused by protection fat with Citrus hystrix causes a lot of fat escapes from rumen microbial degradation and accumulate in lamb meat, thereby reducing the water content of meat, because fat content negatively correlated to the water content, ie, the higher fat content of meat, the water content decreases. The water content in the study ranged from $71.69-75.31 \%$, is not much different from research of Tiven et al. (2015), which protects CPO using formaldehyde, with water content of meat lamb ranged at $73.95-76.78 \%$.

\section{Protein Content}

Statistical analysis showed that the treatment was significant $(\mathrm{P}<0.01)$ on protein content of lamb meat. Protein content in lamb meat of P2 diet was higher than P1, but not significant from $\mathrm{P} 0$. This increase was due to the bond between the proteins from skim milk with the aldehyde from Citrus hystrix, which reduces protein degradation in the rumen by microbes, so that it can accumulate in the meat. Protein content in P1 in lower because the fat was not protected, will defaunating rumen microbial so many dead and enzymes for feed digestion becomes inactive, thereby disrupting digestion of feed. According to Drackley (2007), the fat with high of unsaturated fatty acids is toxic to many species of rumen 
Table 2. The Average Chemical Composition (\%) of Lamb Meat with Fat Protection

\begin{tabular}{lccc}
\hline \multirow{2}{*}{ Meat Chemical Composition } & \multicolumn{3}{c}{ Treatment } \\
\cline { 2 - 4 } \multicolumn{1}{c}{ Pater content } & $75.31 \pm 0.18^{\mathrm{a}}$ & $74.28 \pm 0.07^{\mathrm{b}}$ & \multicolumn{1}{c}{ P2 } \\
\hline Protein content & $17.24 \pm 0.44^{\mathrm{a}}$ & $16.41 \pm 0.01^{\mathrm{b}}$ & $17.24 \pm 0.53^{\mathrm{c}}$ \\
Fat content & $3.41 \pm 0.26^{\mathrm{c}}$ & $4.34 \pm 0.14^{\mathrm{b}}$ & $7.47 \pm 0.09^{\mathrm{a}}$ \\
Ash content & $2.37 \pm 0.10^{\mathrm{b}}$ & $2.53 \pm 0.02^{\mathrm{a}}$ & $2.20 \pm 0.02^{\mathrm{c}}$ \\
\hline
\end{tabular}

Different superscripts in the same row indicate significantly different $(\mathrm{P}<0.01)$

bacteria, mainly involved in the digestion of fiber, because fat can wrap feed particles and the cell membranes of microbes, thereby disrupting the production enzymes to feed degradation (Johnson, 2007). Fat protection did not disturb feed digestion by rumen microbes, so it will be available $\mathrm{NH}_{3}$ and VFA to forming carbon chain for microbial protein synthesis, which in turn will accumulate in the meat. Microbial protein synthesis, requires energy balance in the form of VFA and Nitrogen in the form of $\mathrm{NH}_{3}$. The protein content in this study ranged at 16.41$17.24 \%$. Meat contains protein around $19 \%$ in the range between 16-22\% (Forrest et al., 1975). The protein content in this study was lower than the research of Tiven et al. (2015) that protects the CPO using formaldehyde, obtain the protein content of lamb meat ranged from 18.21-19.62\%.

\section{Fat Content}

Statistical analysis showed that the treatment was significant $(\mathrm{P}<0.01)$ on fat content of lamb meat. The results showed that fat content in $\mathrm{P} 1$ was higher than P0. This increase is due to the addition of fat in the diet. Increased fat levels in line with Tiven (2015), that the fat protected with formaldehyde (R2) can increase the fat content of lamb meat at $1.27 \%$ compared to the lamb meat were given basal diet (R0) and lamb meat were given fat without protected formaldehyde (R1) of $0.56 \%$. Increased levels of meat fat is also in line with increased of total fatty acids content in lamb meat on P2 of $1.23 \%$ compared to P0 and $0.99 \%$ compared to P1 (Table 1), which is due to the increase in total SAFA and PUFA by $8.82 \%$ compared to $\mathrm{P} 0$ and $6.71 \%$ compared to the P1. The increase fat content is related to the meat water content, ie the higher water content in the meat, the fat content decreased. Fat content in the study ranged at $3.41-7.47 \%$ (average $5.07 \%$ ). According to Savell and Cross cited by Soeparno (2005), the fat content of beef accepted by consumers is $3-7 \%$. Referring to the statement, the delicacy of lamb meat on these results can be accepted by consumers. Fat content in this study is higher than the research of Tiven et al. (2015) that protects the CPO using formaldehyde and obtained the protein content of lamb meat ranged at $3.12-4.39 \%$ (average $3.78 \%$ ).

\section{Ash Content}

Statistical analysis showed that the treatment was significant $(\mathrm{P}<0.01)$ on ash content of lamb meat. Value ash content in lamb meat were given $\mathrm{P} 2$ diet lower than $\mathrm{P} 0$ and $\mathrm{P} 1$. This is caused the fat protected with Citrus hystrix (P2), causes a lot of fat escapes from rumen microbial degradation and accumulate in the meat, thus lowering the water content of the lamb meat, because fat content negatively correlated to the water content. Most of the minerals contained in a lean meat, because mineral components primarily associated with water and meat protein (Soeparno, 2005), so that the water content decrease in the lamb meat will reduce the ash content in lamb meat. Ash content in this study ranged at $2.20-2.53 \%$ (average 2.37) was higher than the research of Tiven et al. (2015) that protects the CPO using formaldehyde, obtain the ash content value in lamb meat ranged at $1.32-1.39 \%$ (average $1.35 \%$ ).

\section{CONCLUSION}

It can be concluded that the use of Citrus hystrix powder as fat protector can increase content of polyunsaturated fatty acids, protein and fat, but decrease cholesterol content. 


\section{ACKNOWLEDGMENT}

The authors would like to thank Directorate General of Higher Education, Republic of Indonesia, for the financial support through the Fundamental Research 2015 with contract No. 045/SP2H/PL/DIT.LITABMAS/11/ 2015, dated February 5, 2015.

\section{REFERENCES}

AOAC. 2012. Official Methods of Analysis. $19^{\text {th }}$ ed. Association of Official Analytical Chemists. Washington, DC.

Drackley, J. K. 2007. Overview of fat digestion and metabolism in dairy cows. http://www. livestocktrail.illinois.edu/uploads/dairynet/p apers/Overview\%20of \%20Fats\%2004.pdf. [January 11, 2016].

Johnson, M. C. 2007. Understanding Rumen Fermentation: I. Effect of High DHA Algal Oil on Microbial Biohydrogenation and II. Monitoring Microbial Shifts in Response to Antibiotics and Oil Using T-RFLP Analysis. Thesis. Master of Science Nutrition and Animal Science, Raleigh. North Carolina. http://repository.lib.ncsu.edu/ir/bitstream/18 40.16/835/1/etd.pdf [January 11, 2016].

Oramahi, H. A. 2008. Analisis data dengan SPSS \& SAS. Studi Kasus Bidang Pertanian, Kehutanan dan Peternakan. Ardana Media, Yogyakarta.

Soeparno. 2005. Ilmu dan Teknologi Daging.
Cetakan Keempat. Gadjah Mada University Press, Yogyakarta.

Tiven, N. C. 2011. Kajian minyak sawit kasar yang diproteksi dengan formaldehid sebagai aditif pakan untuk meningkatkan kualitas daging domba. Dissertation. Gadjah Mada University, Yogyakarta.

Tiven, N. C, L. M. Yusiati, Rusman and U. Santoso. 2011a. Minimize the hydrogenation of unsaturated fatty acid in rumen with formaldehyde. Indo. J. Chem. 13(2):142-148).

Tiven, N. C, L. M. Yusiati, Rusman and U. Santoso. 2011b. Ketahanan Asam Lemak Tidak Jenuh dalam Crude Palm Oil Terproteksi terhadap Aktivitas Mikrob Rumen Domba in vitro. Media Peternakan. 34(1):42-49).

Tiven, N. C, L. M. Yusiati, Rusman and U. Santoso. 2013. Effect of crude palm oil protection with formaldehyde on hydrogenation of rumen fluid unsaturated fatty acid : Its effect on blood and meat fatty acid. Indo. J. Chem. 13(2):142-148.

Tiven, N. C, L. M. Yusiati, Rusman and U. Santoso. 2015. Effect of crude palm oil (CPO) protected by formaldehyde on physical and chemical quality of lamb. J. Indonesian Trop. Anim. Agric. 40(1):31-36.

Wood, J. D., M. Enser, A. V. Fisher, G. R. Nute, P. R. Sheard, R. I. Richardson, S. I. Hughes, and F. M. Whittington. 2008. Fat deposition, fatty acid composition and meat quality. Review. Meat Sci. 78:343-358. 